\title{
Fishes from the Jaru Biological Reserve, Machado River drainage, Madeira River basin, Rondônia State, northern Brazil
}

\author{
Igor David Costa ${ }^{1 *}$, Willian Massaharu Ohara $^{2} \&$ Missilene Almeida ${ }^{I}$ \\ ${ }^{l}$ Engenharia de Pesca, Rua da Paz, Universidade Federal de Rondônia, Porto Velho, RO, Brazil \\ ${ }^{2}$ Museu de Zoologia da USP, Seção de peixes Nazaré, Universidade de São Paulo, São Paulo, SP, Brazil \\ *Corresponding author: Igor David Costa, e-mail: igorbiologia@yahoo.com.br
}

COSTA, I. D., OHARA, W. M., ALMEIDA, M. Fishes from the Jaru Biological Reserve, Machado River drainage, Madeira River basin, Rondônia State, northern Brazil. Biota Neotropica. 17(1): e20160315. http://dx.doi. org/10.1590/1676-0611-BN-2016-0315

\begin{abstract}
This work assessed freshwater fishes collected at 12 stations located along the Tarumã River, middle Machado River, Madeira River basin. The fieldwork took place in May and September 2015 during the high and low water seasons, respectively. We gathered 1,482 specimens representing seven orders, 30 families, 54 genera and 74 species using seine, gill, and hand nets. The family Characidae was the most representative, exhibiting the highest number of species captured. The species with the greatest abundance were Hemigrammus vorderwinkleri, Hyphessobrycon bentosi, Hemigrammus cf. bellottii, Bryconella pallidifrons, and Apistogramma resticulosa. Two species that remained unidentified are probably a new species. This study represents the third fish survey totally conducted at a Conservation Unit in the Rondônia State, and will certainly provide valuable information for future investigations on biodiversity conservation in the Machado River.
\end{abstract}

Keywords: Amazon, freshwater, conservation, ichthyofauna, inventory.

\section{Peixes da Reserva Biológica do Jaru, drenagem do rio Machado, bacia do rio Madeira, Estado de Rondônia, norte do Brasil}

\begin{abstract}
Resumo: Este trabalho avaliou os peixes de água doce coletados em 12 estações localizadas ao longo do rio Tarumã, médio rio Machado, bacia do rio Madeira. O trabalho de campo ocorreu em maio e em setembro de 2015 durante os períodos de cheia e seca, respectivamente. Um total de 1.482 exemplares, sete ordens, 30 famílias, 54 gêneros e 74 espécies foram amostrados com malhadeiras, picaré e puça. Characidae foi a família com maior número de espécies capturadas. As espécies com maior abundância foram Hemigrammus vorderwinkleri, Hyphessobrycon bentosi, Hemigrammus cf. bellottii, Bryconella pallidifrons e Apistogramma resticulosa. Duas espécies não foram identificadas e provavelmente podem ser novas espécies. Este estudo representa a terceira pesquisa de peixes totalmente realizada em uma Unidade de Conservação no Estado Rondônia, e certamente fornecerá informações valiosas para futuros estudos sobre a conservação da biodiversidade do rio Machado.
\end{abstract}

Palavras-chave: Amazônia, água doce, conservação, ictiofauna, inventário.

\section{Introduction}

Among the 33,984 fish species described around the world (Eschmeyer \& Fong 2016), at least 13,000 varieties are unique to freshwater environments (Nelson et al. 2016). The Neotropical realm (South and Central America) encompasses more than 4,000 valid fish species (Reis 2013), with the Amazon River basin harboring the world's greatest diversity of freshwater fish (Freitas et al. 2010, Winemiller et al. 2016, Reis et al. 2016). To date, most studies of the Amazonian ichthyofaunal diversity have concentrated in the floodplains adjacent to large rivers (cf. Lowe-McConnell 1999) and next to urban areas (Mendonça et al. 2005, Souza et al. 2016). Notwithstanding, there are few reports on the ichthyofauna inhabiting environmental areas of high conservation value (Camargo \& Giarrizzo 2007, Oliveira et al. 2009, Pedroza et al. 2012, Vieira et al. 2016).
Despite concerns about the effectiveness of conservation units in the tropics, there is growing evidence that they have been surprisingly useful tools for curbing deforestation (e.g. Jaru Biological Reserve) (Bruner et al. 2001) or conservation of fish species (Frederico et al. 2016). Historically, the majority of the current protected areas in Brazil were created with disregard for the aquatic environment (Agostinho et al. 2005, Abell et al. 2007). Nevertheless, it is uncontestable that they can protect many water bodies and, thus, play a highly important role in the conservation of freshwater organisms (Agostinho et al. 2005).

This study presents a survey of the ichthyofauna of the Tarumã River, a right-bank tributary of the Machado River, located within the Jaru Biological Reserve. This area displays virtually unchanged habitats in respect to its external environment. As the Tarumã River flows within a legally protected area, the objective of this study is to provide a first 
ichthyofaunal inventory, which may eventually support future studies on fish biology and conservation.

\section{Material and Methods}

\section{Study area}

The Jaru Biological Reserve (Rebio Jaru) was established on July 11, 1979, under Federal Decree-law number 83,716, and is managed by the Instituto Chico Mendes de Conservação da Biodiversidade/Ministério do Meio Ambiente (ICMBio/MMA). Marked by the high degree of conservation, the rain forest of the Rebio Jaru is practically intact. The reserve has a humid tropical climate with temperatures varying between $23^{\circ} \mathrm{C}$ and $26^{\circ} \mathrm{C}$, and the average annual rainfall ranges from 1,700 to 2,400 $\mathrm{mm}$. The dry season occurs between May and October (Justina 2009).

The Rebio Jaru hydrographic network is part of the Machado River Basin located in eastern Rondônia State, northern Brazil. The Tarumã River, the main sub-basin of the Rebio Jaru, runs almost entirely (99\%) within the Rebio Jaru. The average depth of the Tarumã River during the dry season was $2.8 \pm 0.9 \mathrm{~m}$; the average width, $32.8 \pm 7.8 \mathrm{~m}$; and the average water speed, $0.4 \mathrm{~ms}^{-1}$. On the other hand, the average depth, width, and water flow values are $5.6 \pm 1.2 \mathrm{~m} ; 41.9 \pm 4.0 \mathrm{~m}$; and $0.3 \pm 0.1 \mathrm{~ms}^{-1}$ during the wet season, respectively. The Tarumã River has many rapids flowing across the granitic formation of the Serra da Providência and Jamari complex (Justina 2009). The high transparency of the water (average transparency ${ }_{\text {Dry }}=1.2 \pm 2.1 \mathrm{~m}$; and average transparency ${ }_{\text {Wet }}=1.1 \pm 0.4 \mathrm{~m}$ ) due to the low amount of sediment, characterizes the Tarumã as a clear water river.

\section{Data collection}

We performed collections of freshwater fish in the Tarumã River in May and September 2015. Each expedition lasted four days. Our samplings comprised 12 sites in two different aquatic environments: five in the main channel and seven in the small stream channels (igarapés) of the Tarumã River (Table 1, Figure 1).

The physical conditions of some sampling stations in the Tarumã River basin are shown in Figure 2.

Stream 4 (S4) - igarapé, $1.81 \mathrm{~m}$ wide and $0.26 \mathrm{~m}$ deep, preserved riparian vegetation, swift current, sand, pebbles, and dead leaves at the bottom (Figure $2 \mathrm{a}$ ).

Stream 6 (S6) - igarapé, $1.39 \mathrm{~m}$ wide and $0.21 \mathrm{~m}$ deep, preserved riparian vegetation, slow current, sand, pebbles, large branches and trunks, and dead leaves at the bottom (Figure 2b).

River 1 (R1) - stretch, $112 \mathrm{~m}$ wide and $6.2 \mathrm{~m}$ deep located near the mouth of the Tarumã River, preserved riparian vegetation and slow current (Figure 2c).
Stream 5 (S5) - igarapé, $0.70 \mathrm{~m}$ wide and $0.25 \mathrm{~m}$ deep, preserved riparian vegetation, slow current, sand, pebbles, large branches and trunks at the bottom (Figure 2d).

Stream 3 (S3) - igarapé, $1.00 \mathrm{~m}$ wide and $0.21 \mathrm{~m}$ deep, preserved riparian vegetation, swift current, sand, bare ravine, large branches and trunks at the bottom (Figure 2e).

River 4 (R4) - stretch, $30 \mathrm{~m}$ wide and $4.5 \mathrm{~m}$ deep located near the head of the Tarumã River, preserved riparian vegetation, slow current (Figure $2 \mathrm{f}$ ).

We accomplished the collections in the river channels using a total of eight gill nets with standard size meshes of $2 \times 20 \mathrm{~m}$, and fishing nets with mesh sizes varying from 30 to $100 \mathrm{~mm}$ (between opposite knots). The fishing nets were set at each sampling site during the morning, from 8:00 am to $12: 00 \mathrm{pm}$, and at night, from $8: 00 \mathrm{pm}$ to 5:00 am. For the same period, we used a trotline with four $5 / 0$ hooks with ends tied either to the bank vegetation or to mooring spikes. We used some pieces of piranha, Serrasalmus rhombeus Linnaeus 1766, as baits attached to the trotline hooks.

In small streams, the fish collection in a stretch of $80 \mathrm{~m}$ lasted one hour during the daytime. Three collectors used hand gathering techniques with a seine net $(1.5 \times 2 \mathrm{~m}, 2 \mathrm{~mm}$ mesh $)$ and a hand net $(0.5 \times 0.8 \mathrm{~m}, 2 \mathrm{~mm}$ mesh $)$ along the entire stretch, selecting the best technique for each environment. Before the collections, the ends of the sampling sections were blocked with fine-mesh nets ( $5 \mathrm{~mm}$ between opposite knots) to prevent fish escapes, regardless of the capture method used. Abiotic data, such as depth, width, and soil were observed in situ. We sacrificed the specimens in a solution of clove oil (Eugenol, 2 drops per liter; cf. American Veterinary Medical Association 2001). After that, the fish were fixed in $10 \%$ formalin solution and then preserved in $70 \%$ ethanol. For species identifications, we consulted the most currently accepted taxonomic literature and identification keys (Queiroz et al. 2013b). The classification followed Nelson et al. (2016). The specimens were deposited in the Coleção de Peixes, Universidade Federal do Mato Grosso, Cuiabá, MT, Brazil (CPUFMT); Laboratório de Ictiologia de Ribeirão Preto da Universidade de São Paulo, Ribeirão Preto, SP, Brazil (LIRP) and Museu de Zoologia da Universidade de São Paulo, São Paulo, SP, Brazil (MZUSP) (Appendix 1). The fish sampling was authorized by the Instituto Chico Mendes de Conservação da Biodiversidade (ICMBio, License: 48723-2/2015).

\section{Results}

Our sampling comprised 1,482 specimens representing seven orders, 33 families, 54 genera, and 74 species. A total of 1,263 specimens representing six orders, 20 families, and 50 species were collected in the streams and 219 specimens; five orders, 13 families, and 24 species were collected in the river (Table 2). Characiformes, Siluriformes, and Cichliformes represented 59\% (47 species), 21\% (17 species), and 10\%

Table 1. Sampling sites in the Tarumã River basin with environmental classification, geographic coordinates, and altitude.

\begin{tabular}{|c|c|c|c|}
\hline Site & Environments & Geographic coordinates & Altitude (m) \\
\hline R1 & River & $9^{\circ} 27^{\prime} 19^{\prime \prime} \mathrm{S}, 61^{\circ} 40^{\prime} 43^{\prime \prime} \mathrm{W}$ & 75 \\
\hline $\mathrm{R} 2$ & River & $9^{\circ} 32^{\prime} 15^{\prime \prime} \mathrm{S}, 61^{\circ} 40^{\prime} 13^{\prime \prime} \mathrm{W}$ & 90 \\
\hline R3 & River & $9^{\circ} 42^{\prime} 46^{\prime \prime} \mathrm{S}, 61^{\circ} 39^{\prime} 42^{\prime \prime} \mathrm{W}$ & 111 \\
\hline R4 & River & $9^{\circ} 46^{\prime} 23^{\prime \prime} \mathrm{S}, 61^{\circ} 38^{\prime} 45^{\prime \prime} \mathrm{W}$ & 119 \\
\hline R5 & River & $9^{\circ} 47^{\prime} 04^{\prime \prime} \mathrm{S}, 61^{\circ} 40^{\prime} 19^{\prime \prime} \mathrm{W}$ & 141 \\
\hline $\mathrm{S} 1$ & Stream & $9^{\circ} 27^{\prime} 28^{\prime \prime} \mathrm{S}, 61^{\circ} 40^{\prime} 34^{\prime \prime} \mathrm{W}$ & 80 \\
\hline $\mathrm{S} 2$ & Stream & $9^{\circ} 27^{\prime} 51^{\prime \prime} \mathrm{S}, 61^{\circ} 40^{\prime} 8^{\prime \prime} \mathrm{W}$ & 82 \\
\hline $\mathrm{S} 3$ & Stream & $9^{\circ} 31^{\prime} 44^{\prime \prime} \mathrm{S}, 61^{\circ} 40^{\prime} 13^{\prime \prime} \mathrm{W}$ & 90 \\
\hline S4 & Stream & $9^{\circ} 32^{\prime} 31^{\prime \prime} \mathrm{S}, 61^{\circ} 38^{\prime} 54^{\prime \prime} \mathrm{W}$ & 181 \\
\hline S5 & Stream & $9^{\circ} 41^{\prime} 47^{\prime \prime} \mathrm{S}, 61^{\circ} 39^{\prime} 47^{\prime \prime} \mathrm{W}$ & 97 \\
\hline S6 & Stream & $9^{\circ} 44^{\prime} 05^{\prime \prime} \mathrm{S}, 61^{\circ} 39^{\prime} 31^{\prime \prime} \mathrm{W}$ & 126 \\
\hline S7 & Stream & $9^{\circ} 46^{\prime} 58^{\prime \prime} \mathrm{S}, 61^{\circ} 40^{\prime} 11^{\prime \prime} \mathrm{W}$ & 130 \\
\hline
\end{tabular}




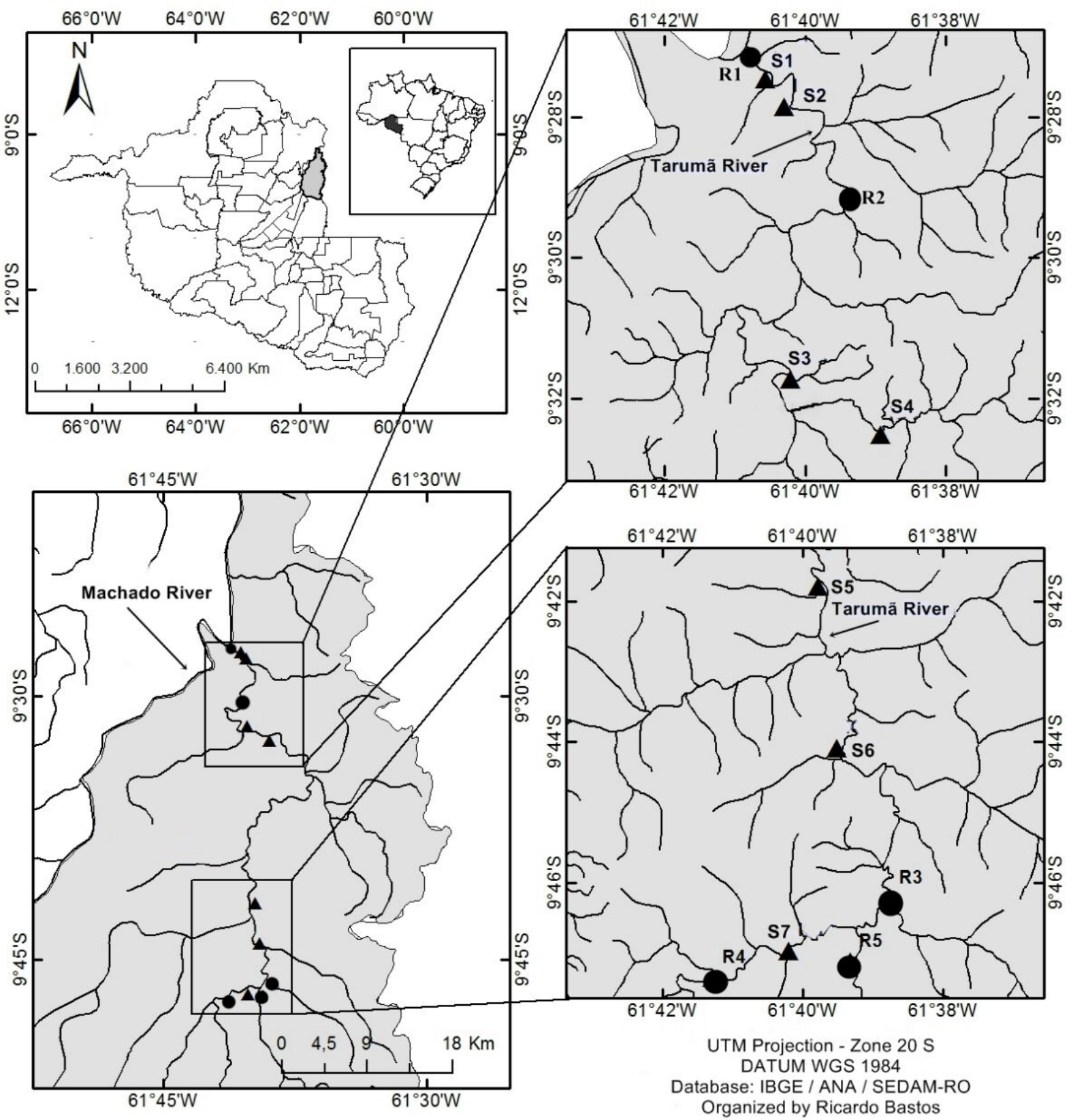

Figure 1. Map of the study area showing the collection stations in the drainage systems in the Jaru Biological Reserve (shaded area), Rondônia, Brazil. Triangles represent streams and circles represent collection points in the river channels of the Tarumã River.

(eight species) of all species, respectively. Nevertheless, Cichliformes were the second most dominant regarding the abundance of capture $(6 \%$, $\mathrm{n}=101)$. The Myliobatiformes, Beloniformes, and Synbranchiformes orders showed richness and abundance lower than $4 \%(n=6)$ and $2 \%(n=6)$, respectively (Figure 3 ). In the streams the Characiformes, Siluriformes, and Cichliformes represented 52\% (26 species), 28\% (14 species), and 10\% (five species) of all species, respectively. Nevertheless, Cichliformes were the second most dominant regarding the abundance of capture $(7 \%, \mathrm{n}=97)$. In the river the results were similar to streams, where the Characiformes, Siluriformes, and Cichliformes represented 75\% (18 species), 8\% (two species), and $8 \%$ (two species) of all species, respectively. The other orders showed richness and abundance lower than 6\% (Table 2). The families with the highest richness and abundance were Characidae (25 species, $31 \% ; n=874,58 \%$ ), Serrasalmidae (six species, $8 \% ; n=129,9 \%$ ), and Cichlidae (seven species, 9\%; $\mathrm{n}=100,7 \%$ ) (Figure 4). In the stream environment the families with the highest richness and abundance were Characidae (18 species, 36\%; $\mathrm{n}=1085,78 \%$ ), Cichlidae (five species, $10 \% ; \mathrm{n}=97,7 \%$ ) and Crenuchidae (four species, $8 \% ; \mathrm{n}=92,6 \%$ ), for the river environment the families Characidae (20 species, $5 \%$; $\mathrm{n}=208$, $50 \%$ ), Serrasalmidae ( 21 species, $5 \% ; \mathrm{n}=127,31 \%$ ), and Cynodontidae (two species, $8 \% ; \mathrm{n}=23,5 \%$ ) were the most representative in richness and abundance. The other families showed richness and abundance lower than 8\% (Table 2). Hemigrammus vorderwinkleri Géry $1963(\mathrm{n}=202)$, Hyphessobrycon bentosi Durbin $1908(\mathrm{n}=196)$, Hemigrammus cf. bellottii 


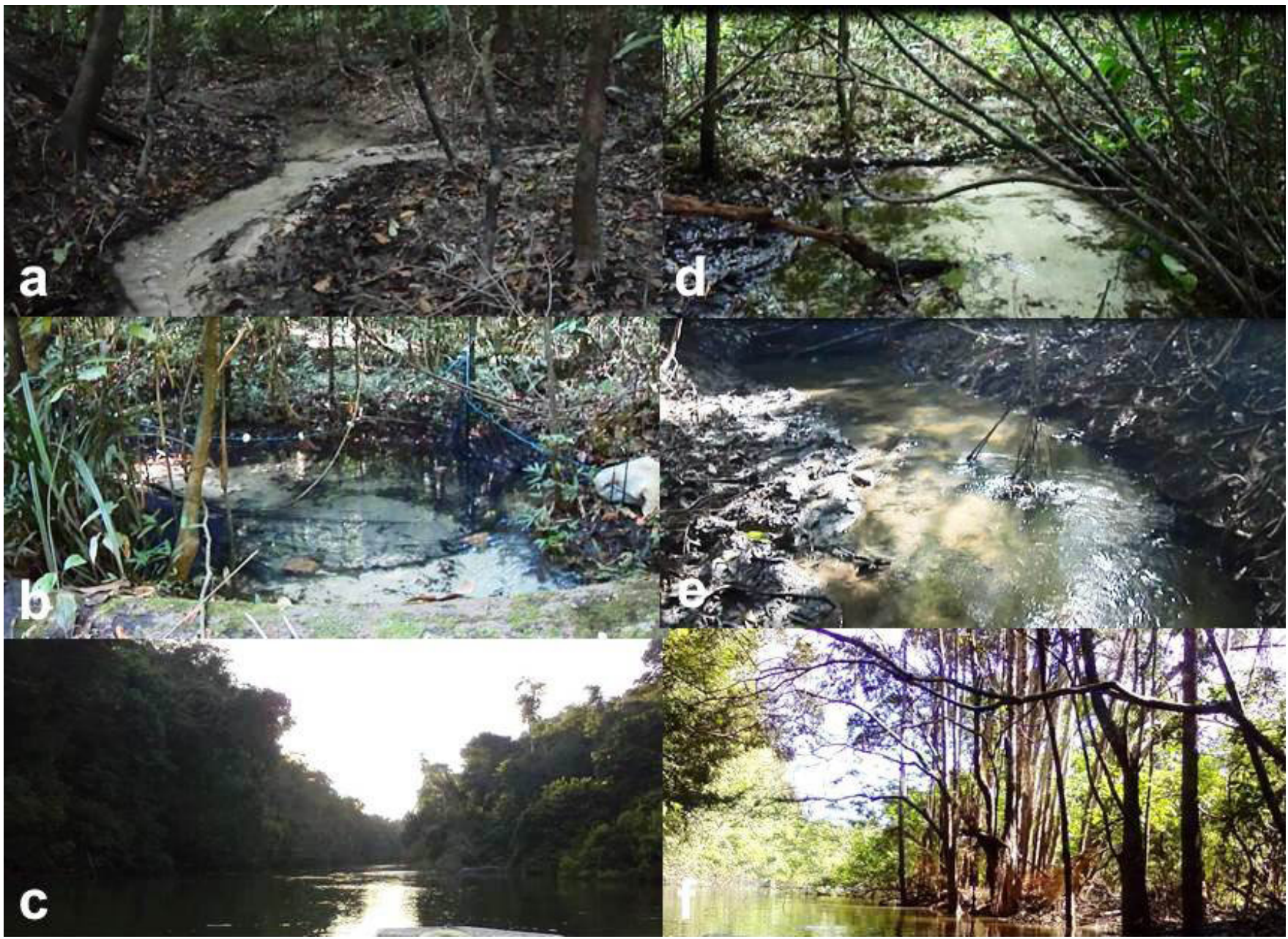

Figure 2. Habitats of some collection stations in the drainage systems in the Jaru Biological Reserve, Tarumã River Basin, Rondônia, Brazil. (a) stream 4; (b) stream 6; (c) stretch 1 of the river channels; (d) stream 5; (e) stream 3; (f) stretch 4 of the river channels.

Steindachner $1882(\mathrm{n}=185)$, Bryconella pallidifrons Fowler $1946(\mathrm{n}=147)$ $(\mathrm{n}=100)$, and Apistogramma resticulosa Kullander $1980(\mathrm{n}=86)$ were the most abundant species in the total of specimens collected and these species also were predominant in the stream environment. The species Serrasalmus rhombeus $(\mathrm{n}=45)$, Serrasalmus compressus $(\mathrm{n}=30)$ and Myloplus lobatus $(\mathrm{n}=24)$ were the most abundant in the river environment.

\section{Discussion}

Most of the several studies conducted in different portions of the Madeira River Basin in the Brazilian territory have focused either on a relatively small area or on specific tributaries. These investigations identified 122 species from the Jamari River (Santos 1996), 133 from the Marmelos River (Camargo \& Giarrizzo 2007), 447 from the Aripuanã and middle Madeira rivers (Py-Daniel et al. 2007), 74 from the Belmont Stream (Araújo et al. 2009), 160 from the Guariba and Roosevelt Rivers (Pedroza et al. 2012), 189 from the Cuniã Lake (Queiroz et al. 2013a), and 174 from the middle Madeira River (Torrente-Vilara et al. 2011). A more comprehensive inventory identified 820 species along the Madeira River Basin (Queiroz et al. 2013b). More specifically, in the Machado River Basin, 48 species were recorded near the urban area of the Cacoal town (Perin et al. 2007), and 140 species in different tributaries (Casatti et al. 2013). However, contrary to the previously mentioned works, only the present study and the assays of Queiroz et al. (2013a) and Vieira et al. (2016) were conducted entirely in a Conservation Unit in the Rondônia State, resulting in the identification of 74,189 , and 141 species, respectively. The current work contributed 24 species to the general inventory of the Machado River and 26 species to the inventory conducted in Conservation Units in the Rondônia State. Additionally, the material deposited in the Brazilian collections enabled the accomplishment of recent taxonomic studies, which contributed to enhancing the knowledge of the ichthyofauna of both the Madeira River (Rocha et al. 2008a, Rocha et al. 2008b, Zanata \& Ohara 2009, Ribeiro et al. 2011, Ohara 2012, Marinho \& Ohara 2013, Zanata \& Ohara 2015, Ohara \& Lima 2015a, Tencatt \& Ohara 2016a, Ohara \& Neuhaus 2016, Tencatt \& Ohara 2016b, Ohara et al. 2016a, Pastana \& Ohara 2016), and the Machado River (Ohara \& Lima 2015b, Ohara \& Marinho 2016, Ohara et al. 2016b).

Among the sampled species from the Tarumã River, almost $44 \%$ (35 species) appear on the list of ornamental fish (Brasil 2012). Some of those species, such as Apistogramma resticulosa, Hemigrammus ocellifer, Hemmigramus vorderwinkleri, Hemmigramus cf. bellottii, Hyphessobrycon bentosi, H. copelandi, Elachocharax pulcher, and Serrasalmus rhombeus (Table 2) were well represented in our survey, suggesting a relatively high local abundance. However, according to the Environmental Crimes Law number 9605 , of February 12,1998 , the capture of ornamental fish in the Rebio Jaru is prohibited (ICMBio 2010). 
Table 2. Fish captured in the Tarumã River, Rondônia, in May and September 2015. Method of collection: T - Trotline, G - Gillnets and S/H - Seine nets (picarés) and hand net (puçá). * Potential for the ornamental fish trade (Brasil 2012), ${ }^{1}$ species additional to species list to studied watershed. Systematic positions were based on Nelson et al. (2016).

\begin{tabular}{|c|c|c|c|}
\hline Class/Order/Family/Species & Streams & River & Method \\
\hline \multicolumn{4}{|l|}{ CLASS CHONDRICHTHYES } \\
\hline \multicolumn{4}{|l|}{ MYLIOBATIFORMES } \\
\hline \multicolumn{4}{|l|}{ Potamotrygonidae } \\
\hline Potamotrygon falkneri Castex \& Maciel $1963^{1}$ & - & 1 & $\mathrm{~T}$ \\
\hline \multicolumn{4}{|l|}{ CLASS OSTEICHTHYES } \\
\hline \multicolumn{4}{|l|}{ CHARACIFORMES } \\
\hline \multicolumn{4}{|l|}{ Acestrorhynchidae } \\
\hline Acestrorhynchus falcatus Bloch 1794* & 2 & - & $\mathrm{S} / \mathrm{H}$ \\
\hline Acestrorhynchus falcirostris Cuvier $1819^{*}$ & - & 2 & $\mathrm{G}$ \\
\hline \multicolumn{4}{|l|}{ Alestidae } \\
\hline Chalceus guaporensis Zanata \& Toledo-Piza 2004 & - & 1 & G \\
\hline \multicolumn{4}{|l|}{ Characidae } \\
\hline Axelrodia stigmatias Fowler 1913 & 7 & - & $\mathrm{S} / \mathrm{H}$ \\
\hline Bario steindachneri Eigenmann 1893 & 1 & - & $\mathrm{S} / \mathrm{H}$ \\
\hline Bryconella pallidifrons Fowler 1946 & 147 & - & $\mathrm{S} / \mathrm{H}$ \\
\hline Brycon amazonicus Spix \& Agassiz 1829 & - & 2 & $\mathrm{G} / \mathrm{T}$ \\
\hline Brycon cf. pesu Müller \& Troschel $1845^{1}$ & - & 3 & G \\
\hline Brycon falcatus Müller \& Troschel $1844^{1}$ & - & 2 & $\mathrm{G}$ \\
\hline Creagrutus anary Fowler $1913^{1}$ & 6 & - & $\mathrm{S} / \mathrm{H}$ \\
\hline Hemigrammus analis Durbin 1909 & 25 & - & $\mathrm{S} / \mathrm{H}$ \\
\hline Hemigrammus cf. bellottii Steindachner 1882* & 185 & - & $\mathrm{S} / \mathrm{H}$ \\
\hline Hemigrammus ocellifer Steindachner 1882* & 45 & - & $\mathrm{S} / \mathrm{H}$ \\
\hline Hemigrammus melanochrous Fowler 1913 & 51 & - & $\mathrm{S} / \mathrm{H}$ \\
\hline Hemigrammus vorderwinkleri Géry 1963* & 202 & - & $\mathrm{S} / \mathrm{H}$ \\
\hline Hyphessobrycon agulha Fowler 1913* & 26 & - & $\mathrm{S} / \mathrm{H}$ \\
\hline Hyphessobrycon copelandi Durbin 1908* & 42 & - & $\mathrm{S} / \mathrm{H}$ \\
\hline Hyphessobrycon bentosi Durbin 1908* & 196 & - & $\mathrm{S} / \mathrm{H}$ \\
\hline Hyphessobrycon sweglesi Géry 1961 & 2 & - & $\mathrm{S} / \mathrm{H}$ \\
\hline Jupiaba zonata Eigenmann $1908^{* 1}$ & 2 & - & $\mathrm{S} / \mathrm{H}$ \\
\hline Moenkhausia collettii Steindachner 1882* & 5 & - & $\mathrm{S} / \mathrm{H}$ \\
\hline Moenkhausia oligolepis Günther 1864* & 10 & - & $\mathrm{S} / \mathrm{H}$ \\
\hline Moenkhausia mikia Marinho \& Langeani 2010 & 1 & - & $\mathrm{S} / \mathrm{H}$ \\
\hline Phenacogaster cf. retropinnus Lucena \& Malabarba $2010^{1}$ & 3 & - & $\mathrm{S} / \mathrm{H}$ \\
\hline Roeboides affinis Günther $1868^{1}$ & - & 4 & G \\
\hline Triportheus albus Cope $1872 *$ & - & 4 & G \\
\hline \multicolumn{4}{|l|}{ Gasteropelecidae } \\
\hline Carnegiella strigata Günther 1864* & 25 & - & $\mathrm{S} / \mathrm{H}$ \\
\hline \multicolumn{4}{|l|}{ Crenuchidae } \\
\hline Characidium cf. pellucidum Eigenmann 1909 & 20 & - & $\mathrm{S} / \mathrm{H}$ \\
\hline Characidium aff. zebra Eigenmann $1909^{1}$ & 2 & - & $\mathrm{S} / \mathrm{H}$ \\
\hline Elachocharax pulcher Myers 1927* & 68 & - & $\mathrm{S} / \mathrm{H}$ \\
\hline Microcharacidium sp. ${ }^{1}$ & 2 & - & $\mathrm{S} / \mathrm{H}$ \\
\hline \multicolumn{4}{|l|}{ Erythrinidae } \\
\hline Hoplias malabaricus Bloch 1794* & 9 & - & $\mathrm{S} / \mathrm{H}$ \\
\hline \multicolumn{4}{|l|}{ Lebiasinidae } \\
\hline Pyrrhulina cf. brevis Steindachner, 1876 & 3 & - & $\mathrm{S} / \mathrm{H}$ \\
\hline \multicolumn{4}{|l|}{ Ctenolucidae } \\
\hline Boulengerella cuvieri Spix \& Agassiz 1829 & - & 16 & G \\
\hline \multicolumn{4}{|l|}{ Hemiodontidae } \\
\hline Hemiodus unimaculatus Bloch 1794 * & - & 1 & G \\
\hline \multicolumn{4}{|l|}{ Anostomidae } \\
\hline Leporinus friderici Bloch 1794 & - & 5 & G \\
\hline \multicolumn{4}{|l|}{ Cynodontidae } \\
\hline Hydrolycus armatus Jardine $1841^{1}$ & - & 17 & $\mathrm{G} / \mathrm{T}$ \\
\hline Hydrolycus tatauaia Toledo-Piza, Menezes \& Santos, 1999*1 & - & 6 & $\mathrm{G}$ \\
\hline Serrasalmidae & & & \\
\hline
\end{tabular}


Table 2. Continued...

\begin{tabular}{|c|c|c|c|}
\hline $\begin{array}{cc}\text { Class/Order/Family/Species } \\
\end{array}$ & Streams & River & Method \\
\hline Myloplus lobatus Valenciennes $1850^{1}$ & - & 24 & $\mathrm{G}$ \\
\hline Myloplus rubripinnis Müller \& Troschel 1844* & - & 24 & G \\
\hline Pygocentrus nattereri Kner 1858* & - & 4 & G \\
\hline Serrasalmus compressus Jégu, Leão \& Santos, $1991^{1}$ & - & 30 & G \\
\hline Serrasalmus rhombeus Linnaeus $1766^{*}$ & - & 45 & G \\
\hline \multicolumn{4}{|l|}{ Prochilodontidae } \\
\hline Prochilodus nigricans Agassiz 1829 & - & 21 & G \\
\hline \multicolumn{4}{|l|}{ SILURIFORMES } \\
\hline \multicolumn{4}{|l|}{ Aspredinidae } \\
\hline Bunocephalus coracoideus Cope $1874 * 1$ & 9 & - & $\mathrm{S} / \mathrm{H}$ \\
\hline \multicolumn{4}{|l|}{ Trichomycteridae } \\
\hline Ituglanis amazonicus Steindachner 1882 & 1 & - & $\mathrm{S} / \mathrm{H}$ \\
\hline \multicolumn{4}{|l|}{ Callichthyidae } \\
\hline Corydoras cf. trilineatus Cope $1872^{1}$ & 1 & - & $\mathrm{S} / \mathrm{H}$ \\
\hline Corydoras cf. armatus Günther $1868^{1}$ & 5 & - & $\mathrm{S} / \mathrm{H}$ \\
\hline \multicolumn{4}{|l|}{ Cetopsidae } \\
\hline Helogenes marmoratus Günther 1863* & 5 & - & $\mathrm{S} / \mathrm{H}$ \\
\hline \multicolumn{4}{|l|}{ Heptapteridae } \\
\hline Mastiglanis asopos Bockmann 1994 & 1 & - & $\mathrm{S} / \mathrm{H}$ \\
\hline Nemuroglanis furcatus Ribeiro, Pedroza \& Rapp Py-Daniel, $2011^{1}$ & 16 & - & $\mathrm{S} / \mathrm{H}$ \\
\hline Pimelodella howesi Fowler 1940 & 4 & - & $\mathrm{S} / \mathrm{H}$ \\
\hline Pimelodella cf. steindachneri Eigenmann $1917^{1}$ & 1 & - & $\mathrm{S} / \mathrm{H}$ \\
\hline \multicolumn{4}{|l|}{ Pseudopimelodidae } \\
\hline Microglanis poecilus Eigenmann 1912*1 & 1 & - & $\mathrm{S} / \mathrm{H}$ \\
\hline \multicolumn{4}{|l|}{ Doradidae } \\
\hline Acanthodoras spinosissimus Eigenmann \& Eigenmann $1888^{* 1}$ & 1 & - & $\mathrm{S} / \mathrm{H}$ \\
\hline Physopyxis lyra Cope 1871 & 1 & - & $\mathrm{S} / \mathrm{H}$ \\
\hline \multicolumn{4}{|l|}{ Loricariidae } \\
\hline Ancistrus sp. & 1 & - & $\mathrm{S} / \mathrm{H}$ \\
\hline Rineloricaria lanceolata Günther 1868* & 2 & - & $\mathrm{S} / \mathrm{H}$ \\
\hline \multicolumn{4}{|l|}{ Pimelodidae } \\
\hline Pimelodus ornatus Kner $1858^{* 1}$ & - & 2 & $\mathrm{~T}$ \\
\hline Platynematichthys notatus Jardine $1841^{1}$ & - & 1 & $\mathrm{~T}$ \\
\hline \multicolumn{4}{|l|}{ GYMNOTIFORMES } \\
\hline \multicolumn{4}{|l|}{ Hypopomidae } \\
\hline Hypopygus lepturus Hoedeman $1962 *$ & 15 & - & $\mathrm{S} / \mathrm{H}$ \\
\hline \multicolumn{4}{|l|}{ Rhamphichthyidae } \\
\hline Gymnorhamphichthys rondoni Miranda-Ribeiro 1920* & 2 & - & $\mathrm{S} / \mathrm{H}$ \\
\hline \multicolumn{4}{|l|}{ Gymnotidae } \\
\hline Gymnotus coropinae Hoedeman 1962 & 8 & - & $\mathrm{S} / \mathrm{H}$ \\
\hline \multicolumn{4}{|l|}{ BELONIFORMES } \\
\hline \multicolumn{4}{|l|}{ Belonidae } \\
\hline Potamorrhaphis guianensis Jardine 1843* & 3 & - & $\mathrm{S} / \mathrm{H}$ \\
\hline \multicolumn{4}{|l|}{ SYNBRANCHIFORMES } \\
\hline Synbranchidae & & & \\
\hline Synbranchus madeirae Rosen \& Rumney 1972 & 2 & - & $\mathrm{S} / \mathrm{H}$ \\
\hline CICHLIFORMES & & & \\
\hline Cichlidae & & & \\
\hline Aequidens cf. tetramerus Heckel 1840* & 4 & - & $\mathrm{S} / \mathrm{H}$ \\
\hline Apistogramma resticulosa Kullander 1980* & 86 & - & $\mathrm{S} / \mathrm{H}$ \\
\hline Crenicara punctulatum Günther 1863* & 3 & - & $\mathrm{S} / \mathrm{H}$ \\
\hline Crenicichla regani Ploeg 1989* & 2 & - & $\mathrm{S} / \mathrm{H}$ \\
\hline Crenicichla santosi Ploeg $1991^{1}$ & 2 & - & $\mathrm{S} / \mathrm{H}$ \\
\hline Cichla pleiozona Kullander \& Ferreira 2006 & - & 2 & G \\
\hline Satanoperca jurupari Heckel 1840* & - & 1 & G \\
\hline ACANTHURIFORMES & & & \\
\hline Sciaenidae & & & \\
\hline Petilipinnis grunniens Jardine \& Schomburgk $1843^{1}$ & - & 1 & G \\
\hline
\end{tabular}




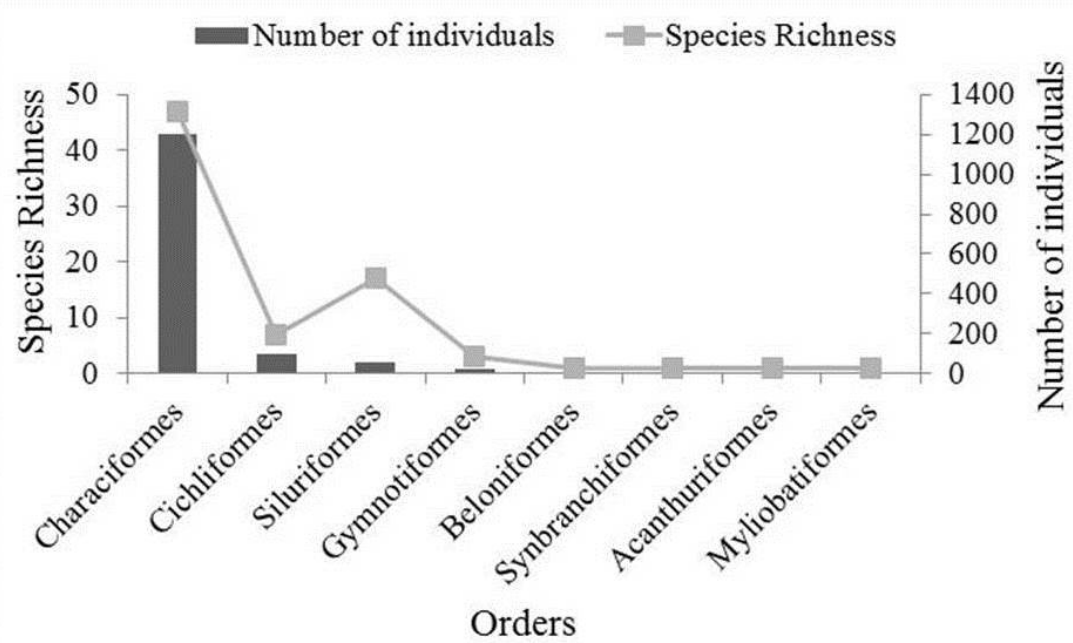

Figure 3. Number of individuals and richness of species of the fish orders collected in the Tarumã River Basin, Rondônia, Brazil.

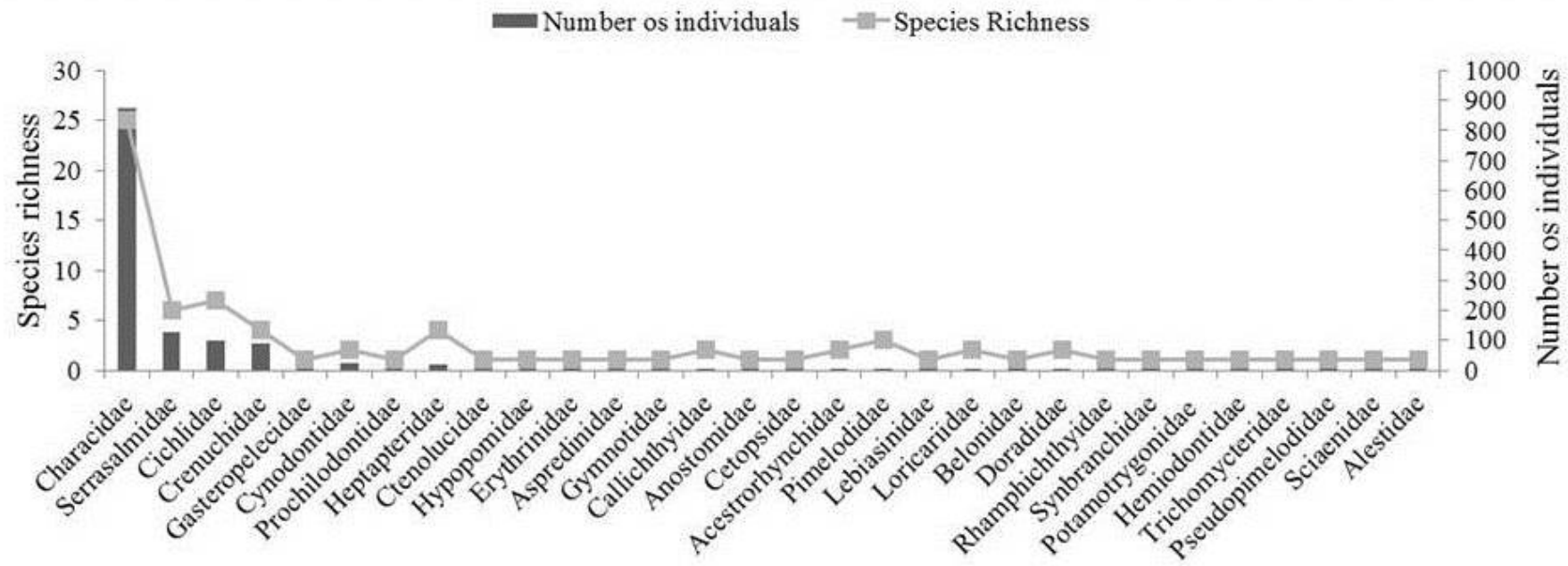

Families

Figure 4. Number of individuals and richness of species of the fish families collected in the Tarumã River Basin, Rondônia, Brazil.

The presence of migratory species in the Tarumã River indicates that this area can be used for reproduction and/or feeding. (Brycon amazonicus Spix \& Agassiz 1829, B. falcatus Müller \& Troschel 1844, Triportheus albus Cope 1872, Prochilodus nigricans Agassiz 1829, Myloplus lobatus Valenciennes 1850, Myloplus rubripinnis Müller \& Troschel 1844, and Platynematichthys notatus Jardine 1841).

Some rare species, considered as such due to their absence in most major ichthyological collections, were recorded in the Tarumã River. These included the Characiformes Axelrodia stigmatias Fowler 1913, Bario steindachneri Eigenmann 1893, Chalceus guaporensis Zanata \& Toledo-Piza 2004, Creagrutus anary Fowler 1913, and Hemigrammus melanochrous Fowler 1913, the Siluriformes, Nemuroglanis furcatus Ribeiro, Pedroza \& Rapp Py-Daniel, 2011, and the Cichliformes, Crenicichla santosi Ploeg 1991. Two taxa were provisionally identified, due to their uncertain taxonomic status. They may be records of new species, such as Microcharacidium sp. (Crenuchidae) and Ancistrus sp. (Loricariidae). We emphasize that none of the sampled species are on the IUCN Red List.
Several species were discriminated with the use of "cf" or "aff", indicating that the number of new species may be higher. For example, the species identified herein as Brycon cf. pesu Müller \& Troschel 1845 belongs to a complex of species, where new species are undergoing a description process (Zanata \& Lima pers. comm.). Several species, namely, Hemigrammus cf. bellottii, Phenacogaster cf. retropinnus Lucena \& Malabarba 2010, Characidium cf. pellucidum Eigenmann 1909, Characidium aff. zebra Eigenmann 1909, Corydoras cf. armatus Günther 1868, and Corydoras cf. trilineatus Cope 1872, belong either to poorly known taxonomic groups or represent still undescribed species, meaning that further taxonomic studies will be necessary.

Our work highlights the importance of conducting studies within protected areas and strengthens the role of territorial spaces with relevant environmental characteristics in a context where only three inventories within 14 Conservation Units in Rondônia have taken place. The presence of protected areas may help mitigate environmental impacts and maintain the biological integrity of a region surrounded by a long history of anthropogenic 
disturbances (deforestation, gold mining, the construction of the BR 364 road and, more recently, the building of large hydroelectric dams).

\section{Appendix 1}

Voucher specimens.

MYLIOBATIFORMES: Potamotrygon falkneri*; CHARACIFORMES: Acestrorhynchus falcatus (MZUSP 118769, MZUSP 118812), Acestrorhynchus falcirostris (UFRO-I 5523, UFRO-I 18313), Axelrodia stigmatias (MZUSP 118772, MZUSP 118786), Bario steindachneri (MZUSP 118734), Bryconella pallidifrons (MZUSP 118744, MZUSP 118791, MZUSP 118724, MZUSP 118759), Brycon amazonicus (MZUSP 14017), Brycon cf. pesu (LIRP 11773, UFRO-I 14213, UFRO-I 15506), Brycon falcatus (LIRP 13045, 10269), Chalceus guaporensis (UFRO-I 4321, UFRO-I 17473), Creagrutus anary (MZUSP 118745, MZUSP 118779), Hemigrammus ocellifer (MZUSP 118738, MZUSP 118767, MZUSP 118798, MZUSP 118725), Hemigrammus cf. bellottii (MZUSP 118765, MZUSP 118741, MZUSP 118790, MZUSP 118733), Hemigrammus melanochrous (MZUSP 118743, MZUSP 118802, MZUSP 118726), Hemigrammus analis (MZUSP 118758, MZUSP 118788), Hemigrammus vorderwinkleri (MZUSP 118766, MZUSP 118794), Hyphessobrycon agulha (MZUSP 118785, MZUSP 118742, MZUSP 118797), Hyphessobrycon copelandi (MZUSP 118763), Hyphessobrycon bentosi (MZUSP 118764, MZUSP 118792), Hyphessobrycon sweglesi (MZUSP 118732), Jupiaba zonata (MZUSP 118762), Moenkhausia oligolepis (MZUSP 118753), Moenkhausia mikia (MZUSP 118755), Moenkhausia collettii (MZUSP 118770), Phenacogaster cf. retropinnus (MZUSP 118754, MZUSP 118789), Roeboides affinis (CPUFMT 3393), Triportheus albus (CPUFMT 3398), Carnegiella strigata (MZUSP 118760), Characidium cf. pellucidum (MZUSP 118757, MZUSP 118801, MZUSP 118727), Characidium aff. zebra (MZUSP 118774, MZUSP 118793), Elachocharax pulcher (MZUSP 118756, MZUSP 118796, MZUSP 118719), Microcharacidium sp. 2 (MZUSP 118781, MZUSP 118778), Hoplias malabaricus (MZUSP 118751, MZUSP 118768, MZUSP 118776, MZUSP 118813), Pyrrhulina cf. brevis (MZUSP 118740, MZUSP 118730), Boulengerella cuvieri (CPUFMT 3392), Hemiodus unimaculatus (UFRO-I 12750, UFRO-I 14109), Leporinus friderici (CPUFMT 3400), Hydrolycus armatus (CPUFMT 3390), Hydrolycus tatauaia (LIRP 10293, 10298), Myloplus lobatus (CPUFMT 3394), Myloplus rubripinnis (CPUFMT 3397), Pygocentrus nattereri (CPUFMT 3401), Serrasalmus compressus (CPUFMT 3399), Serrasalmus rhombeus (CPUFMT 3391), Prochilodus nigricans (CPUFMT 3396); SILURIFORMES: Bunocephalus coracoideus (MZUSP 118784, MZUSP 118747, MZUSP 118787, MZUSP 118714), Ituglanis amazonicus (MZUSP 118808), Corydoras cf. trilineatus (MZUSP 118748), Corydoras cf. armatus (MZUSP 118752), Helogenes marmoratus (MZUSP 118800 , MZUSP 118715), Mastiglanis asopos (MZUSP 118737), Nemuroglanis furcatus (MZUSP 118739, MZUSP 118721, MZUSP 118805), Pimelodella howesi (MZUSP 118782, MZUSP 118736), Pimelodella $\mathrm{cf}$. steindachneri (MZUSP 118729), Microglanis poecilus (MZUSP 118717), Acanthodoras spinosissimus (MZUSP 118810), Physopyxis lyra (MZUSP 118771), Ancistrus sp. 1 (MZUSP 118728), Rineloricaria lanceolata (MZUSP 118735, MZUSP 118773), Pimelodus ornatus (LIRP 11969, 12177), Platynematichthys notatus (UFRO-I 3835); GYMNOTIFORMES: Hypopygus lepturus (MZUSP 118803, MZUSP 118723), Gymnorhamphichthys rondoni (MZUSP 118775, MZUSP 118799), Gymnotus coropinae (MZUSP 118783 , MZUSP 118809, MZUSP 118722); BELONIFORMES: Potamorrhaphis guianensis (MZUSP 118811); SYNBRANCHIFORMES: Synbranchus madeirae (MZUSP 118795, MZUSP 118720); CICHLIFORMES: Aequidens cf. tetramerus (MZUSP 118780, MZUSP 118777, MZUSP 118718 , MZUSP 118814), Apistogramma resticulosa (MZUSP 118761, MZUSP 118806, MZUSP 118731), Crenicara punctulatum (MZUSP 118746, MZUSP 118804), Crenicichla regani (MZUSP 118749), Crenicichla santosi (MZUSP 118750 ,
MZUSP 118807), Cichla pleiozona (CPUFMT 3395), Satanoperca jurupari (UFRO-I 16652, UFRO-I 17429); ACANTHURIFORMES: Petilipinnis grunniens (UFRO-I 4883, LIRP 10405).* In process of deposit in Museu de Zoologia da Universidade de São Paulo, São Paulo, SP, Brazil (MZUSP).

\section{Acknowledgements}

The authors are grateful to the staff members of the Instituto Chico Mendes de Conservação da Biodiversidade (ICMBio) for their help and assistance during the fieldwork. They are also grateful to Michel Gianeti, Aléssio Datovo and Osvaldo Oyakawa (MZUSP) for their curatorial assistance. We thank Felipe Ottoni (UFMA), Vitor Abrahão (MZUSP), Luiz Queiroz (Genebra University), and Luisa Manna (UERJ) for the corrections and suggestions to the manuscript. WMO is supported by FAPESP (grant \# 2013/22473-8).

\section{Author Contributions}

Each author's contributions were as follows: Igor Costa; contribution to data acquisition, analysis and interpretation of data, drafting of the manuscript and critical revision as for important intellectual content. Willian Ohara: contribution to the analysis and interpretation of data, drafting of the manuscript, and critical revision for adding substantive intellectual content. Missilene Almeida: contribution to data acquisition and drafting of the manuscript.

\section{References}

ABELL, R., ALLAN, J.D. \& LEHNER, B. 2007. Unlocking the potential of protected areas for freshwaters. Biological Conservation. 134:48-63.

AGOSTINHO, A.A., THOMAZ, S.M. \& GOMES, L.C 2005. Conservação da biodiversidade em águas continentais do Brasil. Megadiversidade. 1(1):70-78.

AMERICAN VETERINARY MEDICAL ASSOCIATION. 2001. Report of the AVMA panel on euthanasia. JAVMA. 218(5):669-696.

ARAÚJO, T.R.D., RIBEIRO, A.C., DORIA, C.R.D.C. \& TORRENTE-VILARA, G. 2009. Composition and trophic structure of the ichthyofauna from a stream downriver from Santo Antonio Falls in the Madeira River, Porto Velho, RO. Biota Neotropica. 9(3):21-29.

BRASIL. 2012. Ministério da Pesca e Aquicultura, Ministério do Meio Ambiente. Instrução Normativa Interministerial n ${ }^{\circ}$ 1, de 03 de Janeiro de 2012. Estabelece normas, critérios e padrões para a explotação de peixes nativos ou exóticos de águas continentais com finalidade ornamental ou de aquariofilia. Poder executivo, Brasília, DF, 03 jan. 2012.

BRUNER, A.G., GULLISON, R.E., RICE, R. \& FONSECA, G.A. 2001. Effectiveness of parks in protecting tropical biodiversity. Science. 291:125-128.

CAMARGO, M. \& GIARRIZZO, T. 2007. Fish, Marmelos Conservation Area (BX044), Madeira River basin, states of Amazonas and Rondônia, Brazil Check list. 3:291-296.

CASATTI. L., PÉREZ-MAYORGA, M.A., CARVALHO, F.R. \& BREJÃO, G.L. COSTA, I.D. 2013. The stream fish fauna from the rio Machado basin, Rondônia State, Brazil. Check list. 9(6):1496-1504.

COLWELL, N.M. 2013. Test anxiety, computer-adaptive testing, and the common core. Journal of Education and Training Studies. 1(2):50-60.

ESCHMEYER, W.N. \& FONG, J.D. 2016. Catalog of Fishes. http://researcharchive. calacademy.org/research/ichthyology/catalog/fishcatmain.asp (last access in 20/10/2016)

FREDERICO, R.G., OLDEN, J.D. \& ZUANON, J. 2016. Climate change sensitivity of threatened, and largely unprotected, Amazonian fishes. Aquatic Conservation: Marine and Freshwater Ecosystems. 26(1):91-102.

FREITAS, C.E.C., SIQUEIRA-SOUZA, F.K., GUIMARÃES, A.R., SANTOS, F.A., SANTOS, I.L.A. 2010. Interconnectedness during high water maintains similarity in fish assemblages of island floodplain lakes in the Amazonian Basin. Revista Brasileira de Zoologia. 27: 931-938. 
JUSTINA, E.E.D. 2009. Zoneamento geoambiental da reserva biológica do Jaru e zona de amortecimento-RO, como subsídio ao seu plano de manejo. Tese de doutorado, Universidade Estadual Paulista, São Paulo.

LOWE-MCCONNELL, R.H. 1999. Estudos ecológicos de comunidades de peixes tropicais. São Paulo: EDUSP. p.534.

MARINHO, M.M.F. \& OHARA, W.M. 2013. Redescription of Astyanax guaporensis Eigenmann 1911 (Characiformes: Characidae), a small characid from the rio Madeira basin. Zootaxa. 3652(4): 75-484.

MENDONÇA, F.P., MAGNUSSON, W.E. \& ZUANON, J. 2005. Relationships between habitat characteristics and fish assemblages in small streams of Central Amazonia. Copeia. 4:751-764.

NELSON, J.S., GRANDE, T.C. \& WILSON, M.V. 2016. Fishes of the World. John Wiley \& Sons, New Jersey, p.752.

OHARA, W.M. 2012. Engraulisoma taeniatum Castro 1981 (Characiformes: Characidae): Range extension with new records in the rio Madeira basin, Rondônia and Amazonas states, Brazil. Check list. 8(6):1313-1314.

OHARA, W.M. \& LIMA, F.C.T. 2015a. Moenkhausia uirapuru, a new species from the Chapada dos Parecis, rio Guaporé, Mato Grosso, Brazil (Characiformes: Characidae). Ichthyological Explorations of Freshwater Fishes. 26(2):159-170.

OHARA, W.M. \& LIMA, F.C.T. 2015b. Hyphessobrycon lucenorum (Characiformes: Characidae), a new species from the rio Madeira basin, Rondônia State, Brazil. Zootaxa. 3972(4):562-572.

OHARA, W.M. \& MARINHO, M.M.F. 2016. A new species of Moenkhausia Eigenmann (Characiformes: Characidae) from the upper rio Machado at Chapada dos Parecis, rio Madeira basin, Brazil. Neotropical Ichthyology. 14(1):37-43.

OHARA, W.M. \& NEUHAUS, E. 2016. On the type locality of Sorubim trigonocephalus Miranda-Ribeiro 1920 (Siluriformes: Pimelodidae). Zootaxa. 4137(2):291-295.

OHARA, W.M., DAVID, I.C. \& FONSECA, L.M. 2016a. Behaviour, feeding habits and ecology of the blind catfish Phreatobius sanguijuela (Ostariophysi: Siluriformes). Journal of Fish Biology. 89:1285-1301.

OHARA, W.M., TENCATT, L.F.C. \& BRITTO, M.R. 2016b. Wrapped in flames: Corydoras hephaestus, a new remarkably colored species from Rio Madeira basin (Teleostei: Callichthyidae). Zootaxa. 4170(3):539-552.

OLIVEIRA, R.R., ROCHA, M.S., ANJOS, M.B., ZUANON, J. \& PY-DANIEL, L.H.R. 2009. Fish fauna of small streams of the Catua-Ipixuna Extractive Reserve, State of Amazonas, Brazil. Check List. 5:154-172.

PASTANA, M.N.L. \& OHARA, W.M. 2016. A new species of Hyphessobrycon Durbin (Characiformes: Characidae) from rio Aripuanã, rio Madeira basin, Brazil. Zootaxa. 4161(3):386-398.

PEDROZA, W.S., RIBEIRO, F.R.V., TEIXEIRA, T.F., OHARA, W.M. \& PY-DANIEL, L.H.R. 2012. Ichthyofaunal survey of stretches of the Guariba and Rooselvelt rivers, in Guariba State Park and Guariba Extractive Reserve, Madeira River basin, Amazonas, Brazil. Check list. 8:8-15.

PERIN, L., SHIBATTA, O.A. \& BERNARDE, P.S. 2007. Fish, Machado River basin, Cacoal urban area, state of Rondônia, Brazil. Check list. 3(2):94-97.

PY-DANIEL, L.H.R., DEUS, C.P., RIBEIRO, O.M. \& SOUSA, L.M. 2007. Peixes. In: PY-DANIEL L.H.R., DEUS, C.P., HENRIQUES, A.L., PIMPÃO D.M. \& RIBEIRO O.M. (Eds) Biodiversidade do Médio Madeira: bases científicas para proposta de conservação. MMA/MCT, Manaus, p.89-125.

QUEIROZ, L.J., TORRENTE-VILARA, G., VIEIRA, F.G., OHARA, W.M., ZUANON, J. \& DORIA, C.R. 2013a. Fishes of Cuniã Lake, Madeira River Basin, Brazil. Check List. 9:540-548.
QUEIROZ, L.J., TORRENTE-VILARA, G., OHARA, W.M., PIRES, T.H.S., ZUANON, J. \& DORIA, C.R.C. 2013b. Peixes do Rio Madeira. Dialeto Latin American Documentary, São Paulo, p.1163.

REIS, R.E. 2013. Conserving the freshwater fishes of South America. International Zoo Yearbook. 47:65-70.

REIS, R.E., ALBERT, J.S., DI DARIO, F., MINCARONE, M.M., PETRY, P. \& ROCHA, L.A. 2016. Fish biodiversity and conservation in South America. Journal of Fish Biology. 89:12-47.

RIBEIRO, F.R.V., PEDROZA, W.S. \& PY-DANIEL, L.H.R. 2011. A new species of Nemuroglanis (Siluriformes: Heptapteridae) from the rio Guariba, rio Madeira basin, Brazil. Zootaxa. 2799:41-48.

ROCHA, M.S., OLIVEIRA, R.R. \& PY-DANIEL, L.H.R. 2008a. A new species of Gladioglanis Ferraris e Mago-Leccia from rio Aripuanã, Amazonas, Brazil (Siluriformes: Heptapteridae). Neotropical Ichthyology. 6:433-438.

ROCHA, M.S., OLIVEIRA, R.R. \& PY-DANIEL, L.H.R. 2008b. Scoloplax baskini: a new spiny dwarf catfish from rio Aripuanã, Amazonas, Brazil (Loricarioidei: Scoloplacidae). Neotropical Ichthyology. 6:323-328.

SANTOS, G.M. 1996. Impactos Da Hidrelétrica Samuel Sobre As Comunidades De Peixes Do Rio Jamari (Rondônia, Brasil). Acta Amazônica. 25(4): 247-280.

SOUZA, C.L.R.D., COSTA, V.B.D., PEREIRA, S.D.F.P., SILVA, D.C.M.D. \& SARPEDONTI, V. 2016. Impacts of urban life on water quality and fish larvae communities in two creeks of the Brazilian Amazon. Revista Ambiente \& Água. 11(1):13-23.

TENCATT, L.F.C. \& OHARA, W.M. 2016a. Two new species of Corydoras Lacépède 1803 (Siluriformes: Callichthyidae) from the rio Madeira basin, Brazil. Neotropical Ichthyology. 14(1):139-154.

TENCATT, L.F.C. \& OHARA, W.M. 2016b. A new long-snouted species of Corydoras Lacépède 1803 (Teleostei: Callichthyidae) from the rio Madeira basin. Zootaxa. 4133(3):430-442.

TORRENTE-VILARA, G., ZUANON, J., LEPRIEUR, F., OBERDORFF, T. \& TEDESCO, P.A. 2011. Effect of natural rapids and waterfalls on fish assemblage structure in the Madeira River (Amazon Basin). Ecology of Freshwater Fish. 20(4):588-597.

VIEIRA, F.G., MATSUZAKI, A.A., BARROS, B.S.F., OHARA, W.M., PAIXÃO, A.C., TORRENTE-VILARA, G., ZUANON, J. \& DORIA, C.R.C. 2016. Catálogo de Peixes da Estação Ecológica de Cuniã. Edufro, Porto Velho, p.108.

WINEMILLER, K.O., MCINTYRE, P.B., CASTELLO, L., FLUET-CHOUINARD, E., GIARRIZZO, T., NAM, S. \& STIASSNY, M.L.J. 2016. Balancing hydropower and biodiversity in the Amazon, Congo, and Mekong. Science. 351(6269):128-129.

ZANATA, A.M. \& OHARA, W.M. 2009. Jupiaba citrina, a new species from rio Aripuanã, rio Madeira basin, Amazonas and Mato Grosso States, Brazil (Characiformes: Characidae). Neotropical Ichthyology. 7(4):513-518.

ZANATA, A.M. \& OHARA, W.M. 2015. A new species of Characidium Reinhardt (Ostariophysi: Characiformes: Crenuchidae) from headwaters of rio Pacaás Novos, rio Madeira basin, Rondônia, Brazil. Zootaxa. 4021(2):368-376.

Received: 17/12/2016

Revised: 04/01/2017

Accepted: 05/01/2017

Published online: 30/01/2017 